\title{
Calix[4]pyrroles: New Solid-Phase HPLC Supports for the Separation of Anions**
}

\author{
Jonathan L. Sessler,* Philip A. Gale, and John W. Genge
}

\begin{abstract}
The preparation of two distinct calix[4]pyrrole-modified silica gels is reported. These systems, designed to investigate the binding characteristics of calix[4]pyrroles with anionic and neutral substrates, also provide a new solid support for the HPLC separation of nucleotides, oligonucleotides, N-protected amino acids and perfluorinated biphenyls. Binding affinities for the interaction of anions with calix[4]pyrrole amide derivatives are also reported; these were determined from ${ }^{1} \mathrm{H}$ NMR spectroscopic analyses carried out in $\mathrm{CD}_{2} \mathrm{Cl}_{2}$.
\end{abstract}

Keywords: anion binding - HPLC . macrocycles • oligonucleotides • pyrroles

\section{Introduction}

The covalent attachment of molecular receptors to solid supports provides a time-honored means of exploring receptor-substrate interactions. ${ }^{[1-5]}$ Pioneering work in this area by Cram and co-workers produced resins, covalently modified with chiral crown ethers, that proved capable of resolving enantioselectively various amino acid derivatives. ${ }^{[1]}$ Other systems (most notably those of Izatt, Bradshaw, and Christensen), ${ }^{[2]}$ consisting of azacrown ethers attached to silica gels, have proven useful in the separation of mixtures of metal cations. In this classic work and in other instances ${ }^{[3]}$ this approach has allowed binding interactions involving a large number of substrates to be analyzed under identical experimental conditions. As such, it provides a convenient and wellvalidated method of quickly testing the substrate-binding potential of a new receptor or proposed receptor.

The above approach has been extensively exploited in the area of cation recognition and separation; however, it has been less frequently applied in the study of anion binding. One such approach that appears attractive involves the attachment of a metallated porphyrin to either polystyrene or silica gel; ${ }^{[6,7]}$ these systems have been employed in the separation of quite a number of anionic species including iodide, thiocyanate, and benzoic acid derivatives. We have

[*] Prof. J. L. Sessler, Dr. P. A. Gale, J. W. Genge

Department of Chemistry and Biochemistry

The University of Texas at Austin, Austin, TX 78712 (USA)

Fax: $(+1) 512471-7550$

E-mail: sessler@mail.utexas.edu

[**] Supporting information for this paper is available on the WWW under http://www/wiley-vch.de/home/chemistry/, or directly from the author. also introduced another anion-separating system that consists, in general terms, of various sapphyrin-modified silica gels (for example gel S). In this case, the resulting solid supports allow the HPLC separation of anions such as phenyl arsenate,

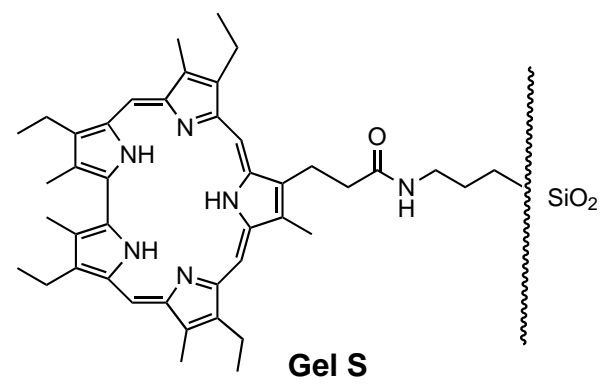

benzenesulfonate, and benzoate, as well as mixtures of nucleotides. ${ }^{[8,9]}$ However, the observation of broad peaks in the case of short (3- to 9-mer) oligonucleotide mixtures as well as the synthetic difficulties associated with preparing functionalized sapphyrins prompted us to search for an alternative chelating group upon which the construction of the anionseparating silica gels could be based. As detailed in this report, the calix[4]pyrroles show promise in this regard.

The calix[4]pyrroles (meso-octaalkylporphyrinogens) are a class of nonaromatic macrocycles first synthesized by Baeyer in $1886^{[10]}$ that act as effective and selective anion-binding agents both in solution and in the solid state. ${ }^{[1-13]}$ In this paper we show two ways of attaching these easily made macrocycles to aminopropyl silica gel. We also show that the resulting supports (gel M and gel B) make HPLC columns that have quite intriguing anion-separating properties. 


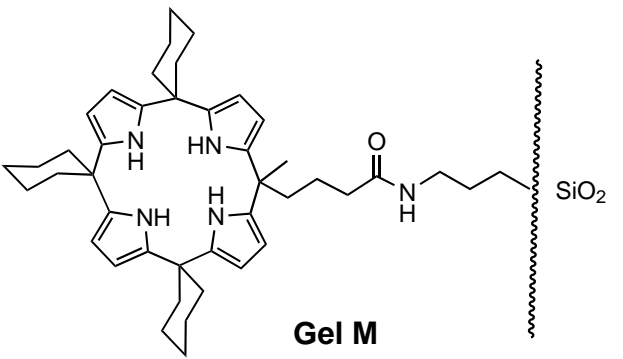

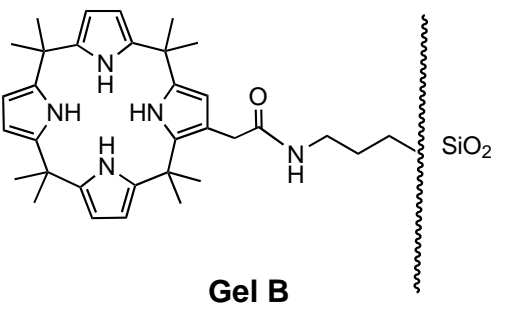

the anion-binding properties of appropriately functionalized amidocalix[4]pyrrole controls in solution.

Initial experiments (using either UV or conductance detection of anions) proved successful, with both gels B and $\mathrm{M}$ selectively retaining a) fluoride, chloride, bromide, hydrogensulfate, and dihydrogenphosphate (see Table 1), b) phenyl arsenate, phenyl phosphate, and phenyl sulfonate (Table 1), c) Cbzprotected anionic amino acids (serine, glutamine, alanine, phenylalanine, tryptophan, aspartate, and glutamate, Figure 1).

Table 1. Retention of anions by gels B and M.

\begin{tabular}{llc}
\hline Anion & \multicolumn{2}{c}{ Elution times [min] } \\
& Silica gel B & Silica gel M \\
\hline chloride $^{[\mathrm{b}]}$ & $17.9( \pm 0.1)^{[\mathrm{a}]}$ & $15.2( \pm 0.1)^{[\mathrm{a}]}$ \\
dihydrogenphosphate $^{[\mathrm{b}]}$ & $22.0( \pm 0.1)^{[\mathrm{a}]}$ & $20.1( \pm 0.1)^{[\mathrm{a}]}$ \\
hydrogensulfate $^{[\mathrm{b}]}$ & $16.2( \pm 0.1)^{[\mathrm{a}]}$ & $16.2( \pm 0.2)^{[\mathrm{a}]}$ \\
fluoride $^{[\mathrm{b}]}$ & $16.9( \pm 0.1)^{[\mathrm{a}]}$ & $16.4( \pm 0.2)^{[\mathrm{a}]}$ \\
phenyl arsenate $^{[\mathrm{c}]}$ & n.d. & $4.9( \pm 0.1)$ \\
benzoate $^{[\mathrm{d}]}$ & n.d. & $6.9( \pm 0.1)$ \\
benzenesulfonate $^{[\mathrm{d}]}$ & n.d. & $7.0( \pm 0.1)$ \\
phenyl phosphate $^{[\mathrm{d}]}$ & n.d. & $15.1( \pm 0.1)$ \\
\hline
\end{tabular}

[a] Times given for individual elution of tetrabutylammonium anions. [b] Anions were eluted as $1 \mathrm{~mm} \mathrm{CH}_{3} \mathrm{CN}$ solutions of their tetrabutylammonium salts under the following conditions: mobile phase $\mathrm{CH}_{3} \mathrm{CN}$; flow rate $0.40 \mathrm{~mL} \mathrm{~min}^{-1}$; detection by conductivity; column temperature $25^{\circ} \mathrm{C}$. [c] Anions were eluted as $1 \mathrm{~mm}$ aqueous solutions under the following conditions: mobile phase $50 \mathrm{~mm}$ phosphate buffer, $\mathrm{pH}=7.0$, flow rate $0.3 \mathrm{~mL} \mathrm{~min}^{-1}$, column temperature $25^{\circ} \mathrm{C}$, detection $\mathrm{UV}=254 \mathrm{~nm}$. [d] n.d. $=$ not determined.

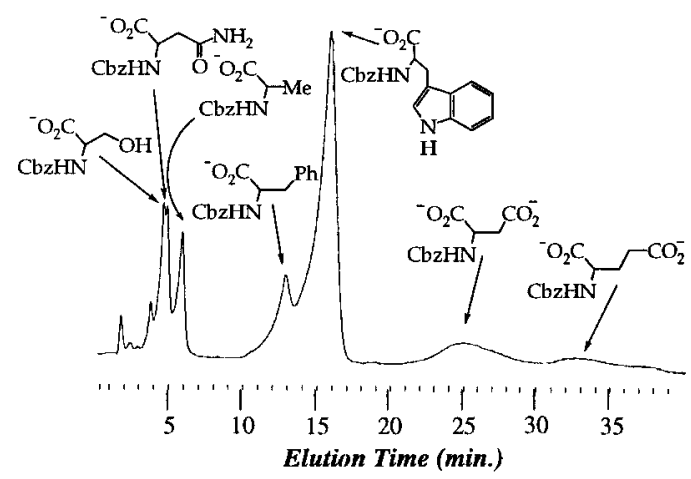

Figure 1. HPLC separation of Cbz-N-protected amino acids on a calixpyrrole-modified silica gel column, prepared from gel M. Flow rate $0.3 \mathrm{~mL} \mathrm{~min}^{-1}$, mobile phase $70 / 30,30 \mathrm{~mm}$ acetate buffer at $\mathrm{pH} 7.0 /$ acetonitrile $(v / v)$ (isochratic), column temperature $25^{\circ} \mathrm{C}, \mathrm{UV}$ detection at $254 \mathrm{~nm}$. and 4 with $n$-butylamine in the presence of (1-benzotriazolyl)oxy tris(dimethylamino)phosphonium hexafluorophosphate $\left(\mathrm{BOP} \mathrm{PF}_{6}\right){ }^{[15]}$ These latter materials were used to study

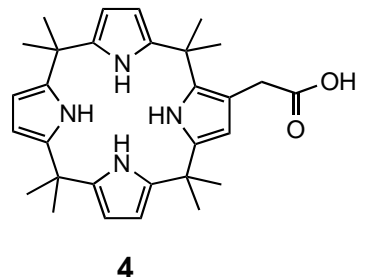

latter materials were then coupled to aminopropyl silica gel with standard amide-coupling conditions ${ }^{[14]}$ to produce two new silica gel solid supports containing amidocalix[4]pyrrole groups [gel M (meso-hook) and gel B ( $\beta$-hook)]. Model compounds 5 and $\mathbf{6}$ were synthesized by coupling acids $\mathbf{3}$
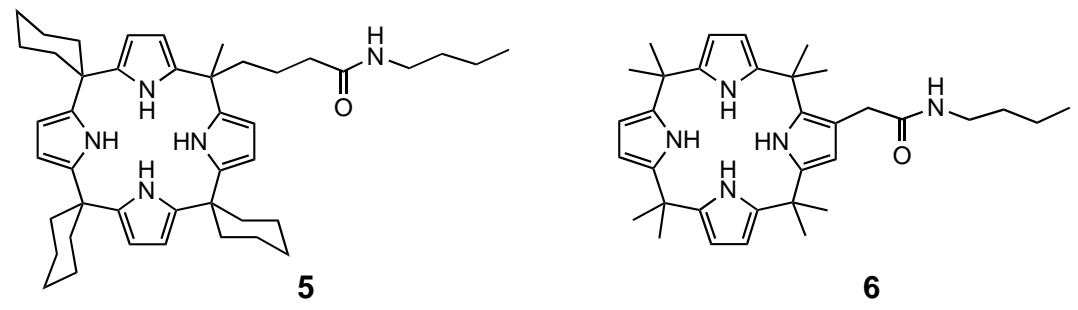

The next set of substrates tested were the phosphorylated derivatives of adenine. The results are illustrated by Figure 2, which shows the HPLC separation of 5'-adenosine monophosphate (AMP), 5'-adenosine diphosphate (ADP) and 5'-adenosine triphosphate (ATP) on gel M. The order of elution differs from that obtained on other neutral solid supports used for anion separations, 
including standard reverse-phase liquid chromatography, ${ }^{[16]}$ in that the more highly charged nucleotide is retained longer without the use of ion-pairing agents. This is presumably due to the higher charge density present in the di- and triphosphate anions, which permits these substrates to interact more favorably with the calix[4]pyrrole subunits present on the column. Thus, the greater the number of phosphate groups, the longer the retention time.

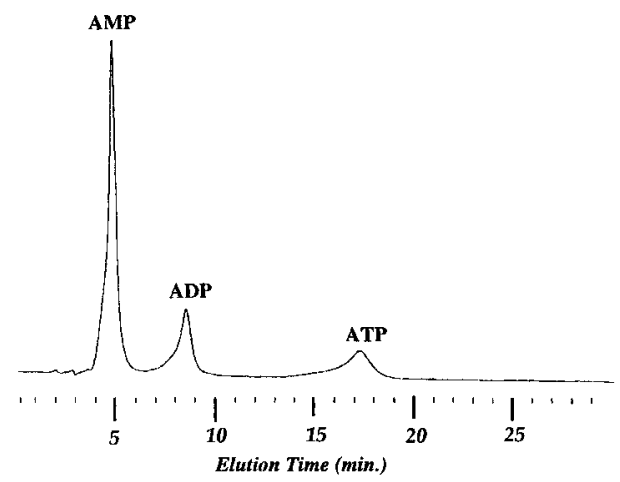

Figure 2. HPLC separation of AMP, ADP, and ATP on the calixpyrrole column derived from gel $\mathrm{M}$. Flow rate $0.3 \mathrm{~mL} \mathrm{~min}^{-1}$, mobile phase $200 \mathrm{~mm}$ sodium phosphate (isochratic), $\mathrm{pH} 7.0$, column temperature $25^{\circ} \mathrm{C}, \mathrm{UV}$ detection at $262 \mathrm{~nm}$.

On the basis that the above suppositions are true, it is predicted that silica gels $\mathrm{M}$ and $\mathrm{B}$ should function as efficient supports for the separation of medium-length oligonucleotides, molecules that are important in both molecular biology and medicine (e.g. antisense technologies). ${ }^{[17]}$ Figure 3 shows the separation on gel $\mathrm{B}$ of a mixture of unprotected oligodeoxyadenylate fragments (dA) containing between 12 and 18 nucleotide subunits. As expected, the species containing

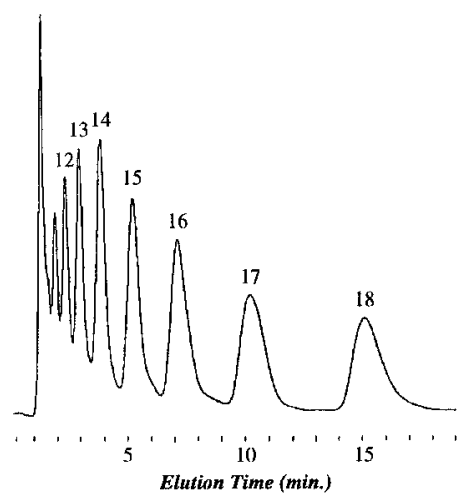

Figure 3. HPLC separation of $\mathrm{dA}_{12-18}$ on the calixpyrrole column derived from gel B. Flow rate $0.4 \mathrm{~mL} \mathrm{~min}^{-1}$, mobile phase $50 / 50, \mathrm{CH}_{3} \mathrm{CN} / 50 \mathrm{~mm}$ sodium chloride $: 40 \mathrm{~mm}$ sodium phosphate $(v / v)$ (isochratic), $\mathrm{pH} 7.0$, column temperature $25^{\circ} \mathrm{C}$, UV detection at $265 \mathrm{~nm}$.

the greater numbers of phosphate groups display the longer retention times, a result that was confirmed in studies involving a similar mixture of unprotected oligodeoxythymidylates (data not shown). Interestingly, both gels $\mathrm{B}$ and $\mathrm{M}$ were found to be capable of separating three oligonucleotide hexamers of equal charge and length (Figure 4). In these cases

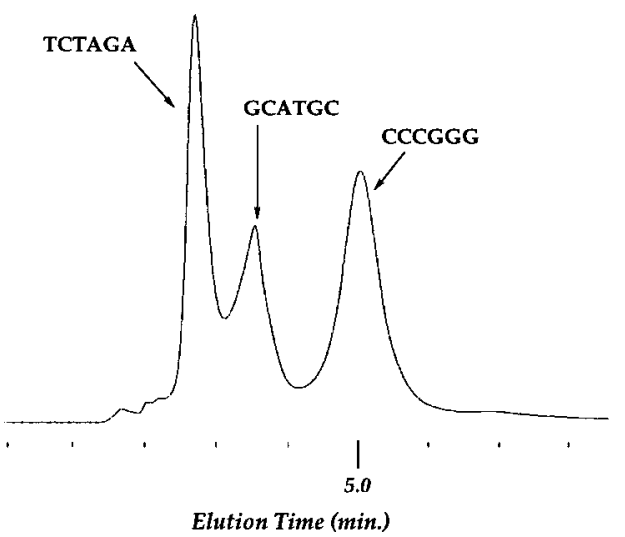

Figure 4. HPLC separation of hexamers: TCTAGA, GCATGC, and CCCGGG on the calixpyrrole column derived from gel M. Flow rate $0.4 \mathrm{~mL} \mathrm{~min}^{-1}$, mobile phase $50 / 50, \mathrm{CH}_{3} \mathrm{CN} / 50 \mathrm{~mm}$ sodium phosphate buffer $(v / v)$ (isochratic), $\mathrm{pH}=7.0$, column temperature $25^{\circ} \mathrm{C}$, UV detection at $265 \mathrm{~nm}$.

the separation presumably reflects the different number of hydrogen bonds that are possible for the various nucleobases of which these oligonucleotides are comprised. This critical finding supports the contention that calixpyrrole-based solid supports could provide a new nonelectrophoretic HPLC method for anionic and oligonucleotide separations that could usefully complement reverse-phase, ${ }^{[18]}$ ion-pair, ${ }^{[19]}$ size-exclusion, ${ }^{[20]}$ or ion-exchange chromatography, ${ }^{[21]}$ as well as capillary electrophoresis. ${ }^{[22]}$ The ease of synthesizing a functionalized calixpyrrole and the fact that unprotected oligonucleotides may be separated are possible advantages, especially with nonanalytical (i.e. preparative) applications.

It quickly became apparent that calix[4]pyrrole silica gels are more easily synthesized than the corresponding sapphyrin-based systems; however, we were also interested in ascertaining whether gels $\mathrm{M}$ and $\mathrm{B}$ in fact performed better when used as anion-separating HPLC supports. We therefore chose to investigate the separation of the same unprotected mixture of oligodeoxyadenylate 12-18 mers using the sapphyrin gel S (Figure 5) as previously studied with the calix[4]pyrrole support gel B (Figure 3). Comparison of Figures 3 and 5 shows that, under identical conditions of elution, the sapphyrin column fails to effect a clean separation, whereas gel B clearly does. While not a complete proof of

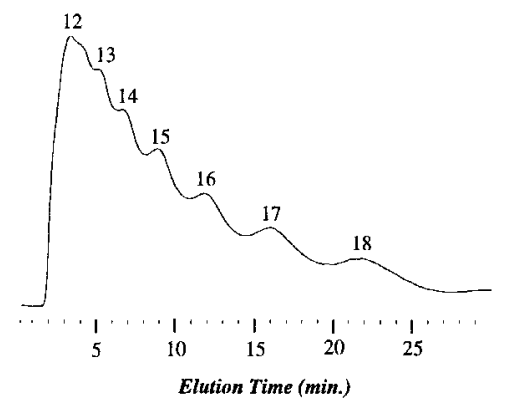

Figure 5. HPLC separation of $\mathrm{dA}_{12-18}$ on the sapphyrin column derived from gel S. Flow rate $0.4 \mathrm{mLmin}^{-1}$, mobile phase $50 / 50, \mathrm{CH}_{3} \mathrm{CN} / 50 \mathrm{~mm}$ sodium chloride: $40 \mathrm{~mm}$ sodium phosphate $(v / v)$ (isochratic), $\mathrm{pH} 7.0$, column temperature $25^{\circ} \mathrm{C}$, UV detection at $265 \mathrm{~nm}$. 
superiority, the apparently improved separation observed with the calixpyrrole support can be rationalized in terms of the different binding characteristics involved. Specifically, 3,12,13,22-tetraethyl-2,7,18,23-tetramethyl-8,17-di(hydroxypropyl)sapphyrin ${ }^{[23]}$ shows a higher affinity for the phosphate anion $\left(K_{\mathrm{a}}=1 \times 10^{4} \mathrm{M}^{-1}\right.$ in methanol $)$ than $\beta$-hydroxycarbonylmethyl-meso-octamethylcalix[4]pyrrole $4 \quad\left(K_{\mathrm{a}}<15 \mathrm{M}^{-1}\right.$ in methanol). ${ }^{[24]}$ The higher affinity of sapphyrin towards anionic species presumably hinders the release of the anion from the sapphyrin subunit, thereby causing broad, ill-defined peaks.

To further assess the extent to which binding affinities correlate with observed separation efficiencies, the chloride-, dihydrogenphosphate-, and hydrogensulfate-binding properties of compounds $\mathbf{5}$ and $\mathbf{6}$ were analyzed in solution. The relevant studies were carried out in $\mathrm{CD}_{2} \mathrm{Cl}_{2}$ (for reasons of solubility) with the stability constants and binding stoichiometries (1:1 in all instances) being determined by ${ }^{1} \mathrm{H}$ NMR titration. ${ }^{[25]}$ As can be deduced from the results in Table 2, these analyses do in fact provide a basis for understanding the calix[4]pyrrole-related HPLC results discussed above. For instance, on both silica gels $\mathrm{M}$ and $\mathrm{B}$, phenyl phosphate is retained on the column longer than, and hence readily separated from, benzenesulfonate; this can be explained in terms of the fact that dihydrogenphosphate forms a stronger bond to the model compounds 5 and $\mathbf{6}$ than hydrogensulfate. ${ }^{[26]}$ Likewise, similar retention times are observed when either gel $\mathrm{M}$ or $\mathrm{B}$ is used to separate, for example, $\mathrm{H}_{2} \mathrm{PO}^{4-}$; this could reflect the fact that nearly identical $K_{\mathrm{a}}$ 's for this substrate are displayed by both 5 and $\mathbf{6}$ in $\mathrm{CD}_{2} \mathrm{Cl}_{2}$ solution.

Table 2. The anion-binding properties of compounds 5 and $\mathbf{6}$ in $\mathrm{CD}_{2} \mathrm{Cl}_{2}$ solution.

\begin{tabular}{lcc}
\hline Anion $^{[\mathrm{a}]}$ & \multicolumn{2}{c}{ Stability constants $\left[\mathrm{M}^{-1}\right]$} \\
& Compound $\mathbf{5}$ & Compound $\mathbf{6}$ \\
\hline Chloride & $415( \pm 45)$ & $405( \pm 10)$ \\
Dihydrogenphosphate & $62( \pm 6)$ & $80( \pm 15)^{[\mathrm{b}]}$ \\
Hydrogensulfate & $<10$ & $<10$ \\
\hline
\end{tabular}

[a] Anions were added as $0.1 \mathrm{M} \mathrm{CD}_{2} \mathrm{Cl}_{2}$ solutions of their tetrabutylammonium salts to $10 \mathrm{~mm}$ solutions of the receptor in $\mathrm{CD}_{2} \mathrm{Cl}_{2}$ with concentration changes being accounted for by EQNMR. ${ }^{[25]}$ In determining the stability constants, the possible effects of ion pairing (if any) were ignored. [b] Estimated value. The $\mathrm{NH}$ proton resonance broadened considerably during the titration, forcing manual notation of the resonance frequency. This value should, therefore, be treated with caution.

In addition to binding anions, calix[4]pyrroles are also known to bind neutral substrates, albeit weakly. ${ }^{[29]}$ Since weak binding interactions can lead to good HPLC separations, ${ }^{[30]}$ we explored whether supports such as $\mathrm{M}$ and B could also be used in neutral substrate separation. As a preliminary test we chose to investigate the separation of polyfluorobiphenyls; these compounds serve as models for the analogous, albeit much more toxic, polychlorobiphenyls (PCBs). As illustrated in Figure 6 , these fluorinated species are readily purified on column B with the more highly substituted substrate perfluorobiphenyl eluted last (similar results were obtained with column M). Such findings are consistent with a mechanism in which separation is achieved, at least in part, on the basis of hydrogen-bonding interactions. In particular, the increased

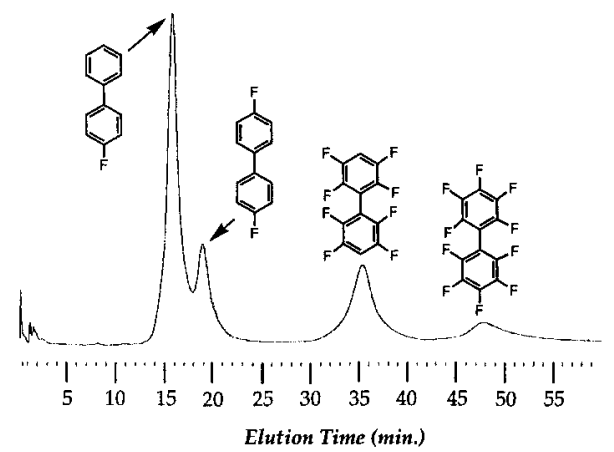

Figure 6. HPLC separation of polyfluorobiphenyls on the calixpyrrole column derived from gel B. Flow rate $0.2 \mathrm{~mL} \mathrm{~min}^{-1}$, mobile phase $76 / 24$ $\mathrm{H}_{2} \mathrm{O} / \mathrm{CH}_{3} \mathrm{CN}(v / v)$, column temperature $25^{\circ} \mathrm{C}$, UV detection at $254 \mathrm{~nm}$.

polarization arising from the presence of the electronegative fluorine substituents allows stronger calixpyrrole-substrate interactions which are analogous to those observed with polyanionic oligonucleotide species. We therefore believe that columns $\mathrm{M}$ and $\mathrm{B}$ could separate a wide range of both neutral and anionic substrates, provided that the substrates differ considerably in their overall polarity.

\section{Experimental Section}

Compounds 1, 2, and $\mathbf{3}$ were synthesized by previously published procedures. ${ }^{[12,13]}$

$\boldsymbol{\beta}$-Hydroxycarbonylmethyl-meso-octamethylcalix[4]pyrrole (4): Compound $2(200 \mathrm{mg}, 0.38 \mathrm{mmol})$ was stirred in $20 \mathrm{~mL}$ of ethanol. This slurry was heated to reflux and $\mathrm{NaOH}_{\mathrm{aq}}(20 \mathrm{~mL}, 2.0 \mathrm{M})$ was added. The reaction mixture was heated under reflux until all the ester had been consumed (approximately 4 hours). The ethanol was then removed in vacuo and a further $50 \mathrm{~mL}$ of cold water added to the solution. The solution was then acidified with concentrated perchloric acid to $\mathrm{pH} 1$. The acid $\mathbf{4}$ precipitated out as a white powder and was collected by filtration and dried under high vacuum, yielding $146 \mathrm{mg}(79 \%) .{ }^{1} \mathrm{H}$ NMR $\left(500 \mathrm{MHz}, \mathrm{CD}_{2} \mathrm{Cl}_{2}\right): \delta=7.84(\mathrm{~s}$, $1 \mathrm{H}, \mathrm{NH}), 7.24(\mathrm{~s}, 1 \mathrm{H}, \mathrm{NH}), 7.01$ (coincident s, 2H, NH), 5.90-5.76 (overlapping m, $\left.5 \mathrm{H}, \mathrm{CH}_{\mathrm{py}}\right), 3.71\left(\mathrm{~s}, 2 \mathrm{H}, \mathrm{OCH}_{2}\right), 1.51\left(\mathrm{~s}, 6 \mathrm{H}, \mathrm{CCH}_{3}\right), 1.50(\mathrm{~s}$, $\left.6 \mathrm{H}, \mathrm{CCH}_{3}\right), 1.48\left(\mathrm{~s}, 6 \mathrm{H}, \mathrm{CCH}_{3}\right), 1.47\left(\mathrm{~s}, 6 \mathrm{H}, \mathrm{CCH}_{3}\right) ;{ }^{13} \mathrm{C}$ NMR $(500 \mathrm{MHz}$ $\left.\mathrm{CD}_{2} \mathrm{Cl}_{2}\right): \delta=179.13(\mathrm{C}=\mathrm{O}), 139.96\left(\mathrm{C}_{\mathrm{py}}\right), 139.20\left(\mathrm{C}_{\mathrm{py}}\right), 139.09\left(\mathrm{C}_{\mathrm{py}}\right), 138.60$ $\left(\mathrm{C}_{\mathrm{py}}\right), 138.52\left(\mathrm{C}_{\mathrm{py}}\right), 137.45\left(\mathrm{C}_{\mathrm{py}}\right), 133.96\left(\mathrm{C}_{\mathrm{py}}\right), 109.27\left(\mathrm{C}_{\mathrm{py}}\right) 107.11(\mathrm{CH})$, $103.21(\mathrm{CH}), 103.14(\mathrm{CH}), 103.05(\mathrm{CH}), 102.91(\mathrm{CH}), 102.75(\mathrm{CH}), 102.14$ $(\mathrm{CH}), 37.20\left(\mathrm{CCH}_{3}\right), 35.49\left(\mathrm{CCH}_{3}\right), 35.40\left(\mathrm{OCH}_{2}\right), 35.23\left(\mathrm{CCH}_{3}\right), 33.68$ $\left(\mathrm{CCH}_{3}\right), 30.38\left(\mathrm{CCH}_{3}\right), 29.16\left(\mathrm{CCH}_{3}\right), 29.09\left(\mathrm{CCH}_{3}\right), 29.00\left(\mathrm{CCH}_{3}\right), 28.85$ $\left(\mathrm{CCH}_{3}\right) ; \mathrm{HRMS}$ (FAB) calcd for $\mathrm{C}_{30} \mathrm{H}_{38} \mathrm{~N}_{4} \mathrm{O}_{2}: 486.2989$, found: $486.2995(\Delta$ $1.1 \mathrm{ppm})$.

meso-Butylamidecalix[4]pyrrole (5): Compound 3 (meso-hook acid, $268 \mathrm{mg}, 0.43 \mathrm{mmol})$ was dissolved in dry DMF $(20 \mathrm{~mL})$ under an argon atmosphere. $n$-Butylamine $(31.6 \mathrm{mg}, 0.43 \mathrm{mmol})$ was added followed by $\mathrm{BOPPF}_{6}(230 \mathrm{mg}, 0.52 \mathrm{mmol})$ and triethylamine $(87 \mathrm{mg}, 0.86 \mathrm{mmol})$. The reaction mixture was stirred for 48 hours. The DMF was then removed in vacuo and the product was purified by silica column chromatography $\left(\mathrm{SiO}_{2}, \mathrm{CH}_{2} \mathrm{Cl}_{2}: \mathrm{CH}_{3} \mathrm{OH}\right.$ 99:1 eluent), which yielded a white foam (118 mg, $41 \%$ ). $1 \mathrm{H} \mathrm{NMR}\left(250 \mathrm{MHz}, \mathrm{CD}_{2} \mathrm{Cl}_{2}\right): \delta=7.26$ (s, 2 H, NH), 7.17 (s, $\left.2 \mathrm{H}, \mathrm{NH}\right)$, $5.93\left(\mathrm{~s}, 2 \mathrm{H}, \mathrm{CH}_{\mathrm{py}}\right), 5.92\left(\mathrm{~s}, 2 \mathrm{H}, \mathrm{CH}_{\mathrm{pv}}\right), 5.90\left(\mathrm{~s}, 2 \mathrm{H}, \mathrm{CH}_{\mathrm{py}}\right), 5.89\left(\mathrm{~s}, 2 \mathrm{H}, \mathrm{CH}_{\mathrm{py}}\right)$, 5.46 (brt, $1 \mathrm{H}, \mathrm{NH}_{\text {amide }}$ ), 3.17 (q, $\mathrm{J}=6.3 \mathrm{~Hz}, 2 \mathrm{H}, \mathrm{CH}_{2}$ ), 1.87 (brcoincident resonances, $18 \mathrm{H}, 9 \mathrm{CH}_{2 \text { cyclohexyl }}$ ), 1.45 (brcoincident resonances, $25 \mathrm{H}$, $\left.6 \mathrm{CH}_{2 \text { cyclohexyl }}+5 \mathrm{CH}_{2 \text { hook }}+\mathrm{CH}_{3 \text { hook }}\right), 0.92\left(\mathrm{t}, J=7.2 \mathrm{~Hz}, 3 \mathrm{H}, \mathrm{CH}_{3}\right) ;{ }^{13} \mathrm{C}$ $\operatorname{NMR}\left(62.90 \mathrm{MHz}, \mathrm{CD}_{2} \mathrm{Cl}_{2}\right): \delta=172.6,137.6,137.2,137.0,136.9,104.0$, 103.9, 103.6, 40.0, 39.8, 39.5, 39.4, 38.8, 37.3, 37.0, 36.7, 32.2, 26.4, 25.6, 23.2, 20.9, 20.5, 14.0; HRMS (FAB) calcd for $\mathrm{C}_{44} \mathrm{H}_{61} \mathrm{~N}_{5} \mathrm{O}: 675.4876$, found: $675.4879(\Delta 1.2 \mathrm{ppm})$.

$\boldsymbol{\beta}$-Butylamidecalix[4]pyrrole (6): Compound 4 ( $\beta$-hook acid, $300 \mathrm{mg}$, $0.62 \mathrm{mmol})$ was dissolved in dry DMF $(20 \mathrm{~mL})$ under an argon atmosphere. 
$n$-Butylamine $(45 \mathrm{mg}, 0.62 \mathrm{mmol})$ was added, followed by BOPPF $_{6}$ $(327 \mathrm{mg}, 0.74 \mathrm{mmol})$ and triethylamine $(125 \mathrm{mg}, 1.2 \mathrm{mmol})$. The reaction mixture was stirred for 48 hours. The DMF was then removed in vacuo and the product was purified by silica column chromatography $\left(\mathrm{SiO}_{2}\right.$, $\mathrm{CH}_{2} \mathrm{Cl}_{2}: \mathrm{CH}_{3} \mathrm{OH}$ 99:1 eluent), which yielded a white foam (331 mg, 99\%). ${ }^{1} \mathrm{H}$ NMR $\left(250 \mathrm{MHz}, \mathrm{CD}_{2} \mathrm{Cl}_{2}\right): \delta=8.80(\mathrm{~s}, 1 \mathrm{H}, \mathrm{NH}), 7.24(\mathrm{~s}, 1 \mathrm{H}, \mathrm{NH}), 7.01$ (coincidents, $2 \mathrm{H}, \mathrm{NH}), 5.92-5.82\left(\mathrm{~m}, 7 \mathrm{H}, 6 \mathrm{CH}_{\mathrm{py}}\right.$ and $\left.\mathrm{NH}_{\text {amide }}\right), 5.70-5.69$ $\left(1 \mathrm{H}, \mathrm{d}, \mathrm{CH}_{\mathrm{py}}\right), 3.51\left(\mathrm{~s}, 2 \mathrm{H}, \mathrm{OCH}_{2}\right), 3.29\left(\mathrm{q}, J=6.2 \mathrm{~Hz}, 2 \mathrm{H}, \mathrm{CH}_{2}\right), 1.66-1.30$ (coincident resonances, $28 \mathrm{H}, 8 \mathrm{CH}_{3 \text { meso }}, 2 \mathrm{CH}_{2 \text { hook }}$ ), $0.96\left(\mathrm{t}, 3 \mathrm{H}, \mathrm{CH}_{3 \text { hook }}\right.$ ); ${ }^{13} \mathrm{C}$ NMR $\left(62.9 \mathrm{MHz}, \mathrm{CD}_{2} \mathrm{Cl}_{2}\right): \delta=173.0,140.2,139.7,139.2,138.9,138.4$, 138.1, 137.4, 134.2, 110.7, 106.9, 103.2, 103.2, 103.1, 102.7, 102.5, 101.6, 39.7, 37.1, 35.9, 35.5, 35.4, 35.2, 32.1, 29.2, 29.0, 28.7, 20.5, 14.0; HRMS (FAB) calcd for $\mathrm{C}_{34} \mathrm{H}_{47} \mathrm{~N}_{5} \mathrm{O}: 541.3781$, found: $541.3782(\Delta 0.2 \mathrm{ppm})$.

Silica gel M: Compound $3(89 \mathrm{mg}, 0.14 \mathrm{mmol})$ was dissolved in dry dichloromethane $(100 \mathrm{~mL})$ under an argon atmosphere and cooled to $0{ }^{\circ}$ C. 1-Hydroxybenzotriazole (HOBT) $(4 \mathrm{mg}, 0.029 \mathrm{mmol})$ and diisopropylcarbodiimide ( $300 \mu \mathrm{l}, 1.91 \mathrm{mmol})$ were added and stirred for 40 minutes at $0{ }^{\circ} \mathrm{C}$. Trimethylsilyl-protected aminopropyl silica gel $(3 \mathrm{~g}, 2 \% \mathrm{w} / \mathrm{w}), 4-$ dimethylaminopyridine $(10 \mathrm{mg}, 0.081 \mathrm{mmol})$, and dry pyridine $(2 \mathrm{~mL}$, $5.5 \mathrm{mmol}$ ) were then added and stirred at room temperature for 4 days. The product was filtered and washed with dichloromethane $(200 \mathrm{~mL})$, methanol $(400 \mathrm{~mL})$, water $(100 \mathrm{~mL})$, and acetonitrile $(250 \mathrm{~mL})$. The silica gel was dried in vacuo for two days and was then resuspended in dry dichloromethane $(100 \mathrm{~mL})$ under an argon atmosphere. The suspension was cooled to $0^{\circ} \mathrm{C}$. Dry pyridine $(5 \mathrm{~mL}, 13.9 \mathrm{mmol})$ and acetyl chloride $(1 \mathrm{~mL}$, $11.4 \mathrm{mmol}$ ) were added and the slurry was stirred at room temperature for 24 hours. The silica gel was filtered and washed using the same procedure described above, and then dried for 24 hours in vacuo and packed into $3.2 \times 100 \mathrm{~mm}$ HPLC columns by Alltech Associates (Deerfield, IL). Efficiency (plates $/ \mathrm{m}^{2}$ ): 14613. Elemental analysis: trimethylsilyl-protected silica gel: C $3.13 \%, \mathrm{H} 0.84 \%, \mathrm{~N} 0.49 \%$; calixpyrrole-substituted silica gel: C $4.23 \%$, H $0.87 \%$, N $0.74 \%$.

Silica gel B: The procedure for the preparation of the modified silica gel was similar to the procedure described above, but using compound $\mathbf{4}$ (100 mg, $0.20 \mathrm{mmol}$ ) instead of compound 3. Efficiency (plates $\left./ \mathrm{m}^{2}\right): 39058$. Elemental analysis: trimethylsilyl-protected silica gel: C 3.13\%, H $0.84 \%$, N $0.49 \%$; calixpyrrole-substituted silica gel: C $3.96 \%$, H $0.85 \%$, N $0.76 \%$.

Acknowledgements: This research was supported by grants from the National Institutes of Health (AI 33577 and TN 00682), the National Science Foundation (CHE 9725399), and the Texas Advanced Technology Program. P.A.G. wishes to thank the Fulbright Commission for a postdoctoral research scholarship.

Received: November 3, 1997 [F 873]

[1] G. D. Y. Sogah, D. J. Cram, J. Am. Chem. Soc. 1976, 98, 3038-3041.

[2] a) R. M. Izatt, R. L. Bruening, B. J. Tarbet, D. L. Griffin, M. L. Bruening, K. E. Krakowiak, J. S. Bradshaw, Pure Appl. Chem. 1990, 62, 1115 -1118. b) J. S. Bradshaw, K. E. Krakowiak, B. J. Tarbet, R. L. Bruening, J. Biernat, M. Bochenska, R. M. Izatt, J. J. Christensen, ibid. 1989, 61, 1619-1624.

[3] a) E. Blasius, K.-P. Janzen, W. Adrian, W. Klein, H. Klotz, H. Luxemburger, E. Mernke, V. B. Nguyen, T. Nguyen-Tien, R. Rausch, J. Stockemer, A. Tossaint, Talanta 1980, 27, 127-141; b) E. Blasius, K.P. Janzen, M. Keller, H. Lander, T. Nguyen-Tien, G. Scholten, ibid. 1980, 27, 107-127; c) A. Mangia, A. Pochini, R. Ungaro, G. D. Andreeti, Anal. Lett. 1983, 16, 1027 -1036; d) S. Fujine, K. Saito, K. Shiba, J. Nucl. Sci. Technol. 1983, 20, 439-440; e) W. M. Feigenbaum, R. H. Michel, J. Polym. Sci. 1971, 9, 817-820; f) A. Warshawsky, R. Kalir, A. Deshe, H. Berkovitz, A. Patchornik, J. Am. Chem. Soc. 1979, 101, 4249-4258; g) K. Kimura, M. Nakajima, T. Shono, Anal. Lett. 1980, A13, 741-750; h) M. Lauth, P. Gramain, J. Liq. Chromatogr. 1985, 8, 2403-2415; i) M. Igawa, K. Saito, J. Tsukamoto, M. Tanaka, Anal. Chem. 1981, 53, $1942-1944$; j) R. B. King, P. R. Heckley, J. Am. Chem. Soc. 1974, 96, 3118-3123; k) W. Smulek, W. A. Lada, Radiochem. Radioanal. Lett. 1977, 30, 199-208; 1) K. Kimura, E. Hayata, T. Shono, J. Chem. Soc. Chem. Commun. 1984, 271-272; m) T. Shinbo, T. Yamaguchi, K. Nishimura, M. Sugiura, J. Chromatogr. 1987,
405, $145-153 ;$ n) L. A. Fernando, M. L. Miles, L. H. Bowen, Anal. Chem. 1980, 52, 1115-1119.

[4] D. M. Kliza, M. E. Meyerhoff, Electroanalysis 1992, 4, 841-849.

[5] M. Takagi, H. Nakamura, J. Coord. Chem. 1986, 15, 53-82.

[6] C. E. Kibbey, M. E. Meyerhoff, Anal. Chem. 1993, 65, 2189-2196.

[7] E. Kokufuta, T. Sodeyama, S. Takeda, Polym. Bull. 1986, 15, 479-484.

[8] B. L. Iverson, R. E. Thomas, V. Král, J. L. Sessler, J. Am. Chem. Soc 1994, 116, 2663-2664.

[9] J. L. Sessler, J. W. Genge, V. Král, B. L. Iverson, Supramol. Chem. 1996, $8,45-52$.

[10] A. Baeyer, Ber. Dtsch. Chem. Ges. 1886, 19, 2184-2185.

[11] P. A. Gale, J. L. Sessler, V. Král, V. Lynch, J. Am. Chem. Soc. 1996, 118, $5140-5141$

[12] P. A. Gale, J. L. Sessler, W. E. Allen, N. A. Tvermoes, V. Lynch, Chem. Commun. 1997, 665-666.

[13] J. L. Sessler, A. Andrievsky, P. A. Gale, V. Lynch, Angew. Chem. 1996, 108, 2954-2957; Angew. Chem. Int. Ed. Engl. 1996, 35, 2782-2785.

[14] A. Tartar, J. -C. Gesquiere, J. Org. Chem. 1979, 44, 5000-5002.

[15] D. Le-Nguyen, A. Heitz, B. Castro, J. Chem. Soc. Perkin Trans. 1 1987, $1915-1919$.

[16] R. Ramage, F. O. Wahl, Tetrahedron Lett. 1993, 34, 7133-7136.

[17] A. M. Gerwitz, C. A. Sein, P. M. Glazeer, Proc. Natl. Acad. Sci. USA 1996, 93, 3161-3163, and references therein.

[18] H. Moriyama, Y. Kato, J. Chromatogr. 1988, 445, 225-233.

[19] J. B. Crowther, R. Jones, R. A. Hartwick, J. Chromatogr. 1981, 217, $479-490$.

[20] D. Molko, R. Derbyshire, A. Guy, A. Roget, R. Teoule, A. Boucherle, J. Chromatogr. 1981, 206, 493-500.

[21] J. D. Pearson, F. E. Regnier, J. Chromatogr. 1983, 255, 137-149.

[22] R. Lehmann, W. Voelter, H. M. Libich, J. Chromatogr. B 1997, 697, 3 35 , and references therein.

[23] a) M. Shionoya, H. Furuta, V. Lynch, A. Harriman, J. L. Sessler, J. Am. Chem. Soc. 1992, 114, 5714-5722; b) J. L. Sessler, M. Cyr, V. Lynch, E. McGhee, J. A. Ibers, ibid. 1990, 112, 2810-2813; c) B. L. Iverson, K. Shreder, V. Král, P. Sansom, V. Lynch, J. L. Sessler, ibid. 1996, 118, 1608-1616; d) B. L. Iverson, K. Shreder, V. Král, D. A Smith, J. Smith, J. L. Sessler, Pure Appl. Chem. 1994, 66, 845-850; e) B. L. Iverson, K. Shreder, V. Král, J. L. Sessler, J. Am. Chem. Soc. 1993, $115,11022-11023$.

[24] This value was determined using ${ }^{1} \mathrm{H}$ NMR titration methods analogous to those reported in ref. [11].

[25] M. J. Hynes, J. Chem. Soc. Dalton Trans. 1993, 311-312.

[26] Interestingly, the stability constants of compound $\mathbf{5}$ are considerably higher than those of the analogous tetraspirocyclohexylcalix[4]pyrrole. ${ }^{[11]}$ Amide groups are known to coordinate to anions in both biotic $^{[27]}$ and abiotic ${ }^{[28]}$ systems. Large chemical shifts of the amide $\mathrm{NH}$ proton of this receptor on addition of anions $(>1.5 \mathrm{ppm}$ in the presence of 5 equiv $\mathrm{Cl}^{-}$) and the enhanced stability constants indicate the involvement of this group in anion binding. Compound 6 has stability constants similar to those of the analogous meso-octamethylcalixpyrrole. ${ }^{[1]}$ In this system, the amide bond must always point directly away from the pyrrolic hydrogen-bonding array of the calixpyrrole, making it unlikely that the amide $\mathrm{NH}$ contributes significantly to the anion chelation process. In fact, the chemical shift of the amide proton alters by only $0.5 \mathrm{ppm}$ in the presence of 6.0 molar equiv of chloride anions.

[27] P. Chakrabarti, J. Mol. Biol. 1990, 34, 463-482.

[28] P. D. Beer, Chem. Commun. 1996, 689-696.

[29] W. E. Allen, P. A. Gale, C. T. Brown, V. Lynch and J. L. Sessler, J. Am Chem. Soc. 1996, 118, 12471-12472.

[30] This is consistent with the finding that calixpyrrole-based columns achieve better HPLC separation of oligonucleotides than columns derived from sapphyrins, even though the latter display higher affinities for phosphate-type substrates; see discussions in text. This contention is further supported by the observation that the sapphyrin silica gel S, with its presumed higher affinity for anions, likewise proved less effective than gel B for the HPLC separation of a mixture of two small anions, namely phenyl phosphate and benzenesulfonate. For instance, under identical, optimized, conditions of elution (flow rate $0.2 \mathrm{~mL} \mathrm{~min}^{-1}$, mobile phase $10 \mathrm{~mm}$ phosphate buffer, $\mathrm{pH} 7.1$, column temperature $25^{\circ} \mathrm{C}$, UV detection at $254 \mathrm{~nm}$ ) gel B gave a baseline separation whereas gel $\mathrm{S}$ did not. 